J. MED. MCROBIOL.-VOL. 16 (1983), 221-226

(C) 1983 The Pathological Society of Great Britain and Ireland

\title{
THE URINARY BACTERIAL FLORA IN PATIENTS WITH THREE TYPES OF URINARY TRACT DIVERSION
}

\author{
M. J. Hill, M. J. Hudson and M. Stewart* \\ Bacterial Metabolism Research Laboratory, PHLS Centre for Applied Microbiology and \\ Research, Porton Down, Salisbury, Wilts, SP4 $3 A J$ and *Institute of Urology, Shaftesbury \\ Avenue, London
}

\begin{abstract}
SUMmaRY. There is known to be a high risk of malignancy at uretero-colic anastomoses and it has been postulated that bacteria catalyse both the local formation and the activation of carcinogens such as $\mathrm{N}$-nitrosamines. If this theory is correct, then the risk of malignancy should be greatest when the prevalence of mixed urinary tract infection is greatest.

Bacterial culture was performed on samples of urine obtained from 56 patients with three forms of urinary tract diversion: ureterosigmoidostomy, isolated ileal and colon conduits. As expected, the rectal urine of all patients with a ureterosigmoidostomy had a rich bacterial flora. However, 11 of the 15 patients with ileal conduits $(73 \%)$ had significant mixed growths of bacteria in the loop urine, whereas only six out of 16 colon loop urines $(37.5 \%)$ were infected, all being monobacterial infections. The implications of these bacteriological findings for carcinogenesis associated with urinary diversion are discussed.
\end{abstract}

\section{INTRODUCTION}

There is a limited range of treatments for patients with severe lower urinary tract pathology which necessitates diversion, such as tuberculosis, exstrophy, incontinence and malignancy. Transplantation of the ureters into the intact colon in man was first described by Stiles in 1911 and, with various modifications, ureterosigmoidostomy remained the most commonly performed diversion until the mid 1950's. The excellent intial results obtained with the isolated ileal conduit described by Bricker (1950) turned most surgeons away from ureterocolic diversions, and the ileal loop soon became, and remains today, the diversion of choice for both benign and malignant disease of the lower urinary tract.

Long term results of ileal diversions have proved disappointing (Dunn et al., 1979), but with the benefit of modern antibiotics, improved surgical techniques and correction of metabolic disturbances the long term results of ureterocolic diversions performed over the last $\mathbf{3 0}$ years compare favourably with those of ileal diversions (Wear and Barquin, 1973; Corbett and Lloyd-Davies, 1976). Good results have been reported with isolated colonic conduits (Mogg, 1965; Althausen, Hagen-Cook and Hendren, 1978) and the rationale of the non-refluxing colon conduit has been summarised by Richie and Skinner (1975), However, although this form of diversion has many protagonists among paediatric urologists (Altwein, Jonas and Hohenfellner, 1977), doubts have been cast upon its superiority over ileal conduits (Elder, Moisey and Rees, 1979).

When urine is infected with a rich mixed bacterial flora, as might be expected in uretero-colic diversions, conditions are ideal for N-nitrosation (Hicks et al., 1977), and we have postulated that these $\mathrm{N}$-nitroso compounds are responsible for the initiation and promotion of the malignancies associated with this form of diversion (Stewart et al., 1981). If this is so, an attempt can be made to assess the risk of malignancy associated with the other types of diversion. Because the composition of the urine is independent of the type of diversion used, the major variable concerned with endogenous $\mathrm{N}$-nitrosation is the bacterial flora. Although there is a copious literature on the bacterial flora of ileal loop urine, similar studies on colon loop urine are

Received 12 Mar. 1982; accepted 22 Sep. 1982

*Present address: Baragwanath Hospital, P.O. Bertsham, Johannesburge 2013, South Africa. 
few and there is no literature comparing the flora of urine from the three types of diversion. In this paper an attempt is made to fill that gap.

\section{PATIENTS AND METHODS}

Patients. The patients studied were attending the Outpatient Department at St Paul's Hospital, London or the Royal Hospital for Sick Children, Great Ormond Street, London, after urinary tract diversion for benign disease, predominantly ectopia vesicae. Of the 56 patients, 25 had ureterosigmoidostomies, 15 had ileal conduits and 16 had colonic conduits.

Fresh loop urine was collected, with strictly aseptic techniques, through a fine Jacques catheter inserted into the stoma. Patients with ureterosigmoidostomies were asked to pass rectal urine directly into sterile receptacles. In each case, $0.5 \mathrm{ml}$ of urine was transferred to a bottle containing $4.5 \mathrm{ml}$ of transport broth (Crowther, 1971) which was immediately frozen at $-30^{\circ} \mathrm{C}$. The samples were transferred in batches to the Bacterial Metabolism Research Laboratory for bacteriological analysis.

Bacteriological methods. The methods used were those described by Borriello, Hudson and Hill (1980). The total nitrate-reducing flora was estimated by the most probable number method of Meynell and Meynell (1970).

\section{RESULTS}

All of the rectal urines, 11 of 15 ileal loop urines and six of 16 colon loop urines were infected with bacteria (fig. 1). When examined for nitrate-reducing bacteria, 23 of the 25 rectal urines

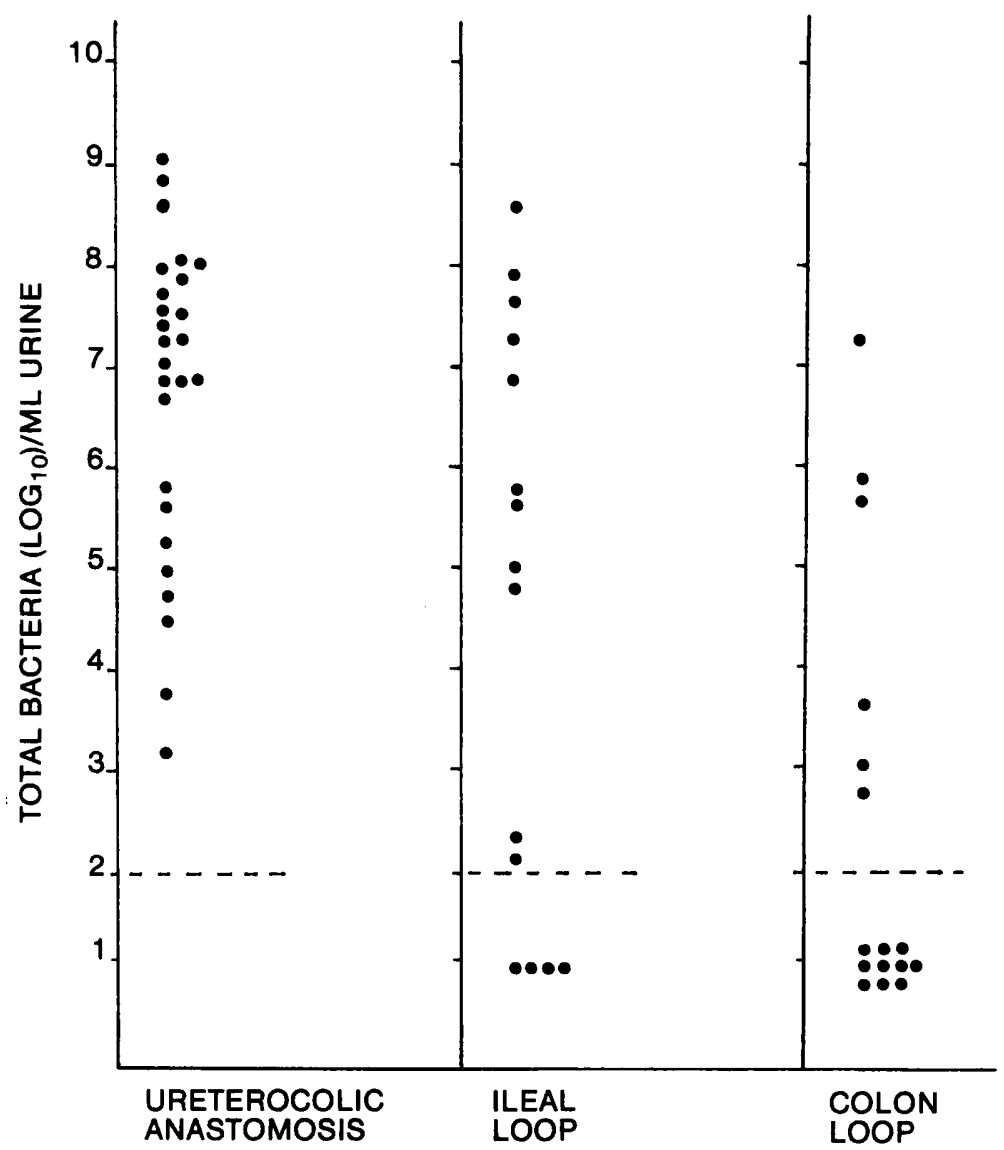

FIG. 1.-The total number of organisms per $\mathrm{ml}$ of urine from 26 patients with ureterocolic anastamoses, 15 with ileal loop and 16 with colon loop diversions. 
contained such organisms, compared with 10 of the 15 ileal and only four of the 16 colon loop urines (fig. 2).

The major organisms isolated from the urine specimens are listed in table I. Rectal urines contained a complex bacterial flora similar to that of faeces, with anaerobic bacteria outnumbering the facultative organisms. The most commonly isolated facultative organisms were streptococci (from 25 of 26 patients) and coliforms (from 20 patients) while the most commonly isolated anaerobes were clostridia (19 patients) and bacteroides (21 patients). Veillonellae and bifidobacteria were present in only seven and three rectal urines respectively. Lactobacilli were isolated from the urines of 10 patients.

The ileal loop urines contained a higher proportion of facultative organisms; of the 11 urines that contained bacteria, nine contained streptococci and seven contained coliforms, whilst bacteroides were isolated from only four patients, clostridia from two and veillonellae from one. None of these urines contained bifidobacteria and only two contained lactobacilli.

The flora of colon loop urines was even simpler; of the six specimens that contained bacteria, four contained only coliforms and two contained only streptococci. The flora of these urinary infections was, therefore, similar in character to that of uncomplicated acute urinary tract infections.

Table II summarizes the complexity of the flora isolated. Only six of the 16 colon loop urines were infected and each contained only a single bacterial genus. In contrast, all of the 26 rectal urines from patients with ureterosigmoidostomies were infected, 23 with three or more genera

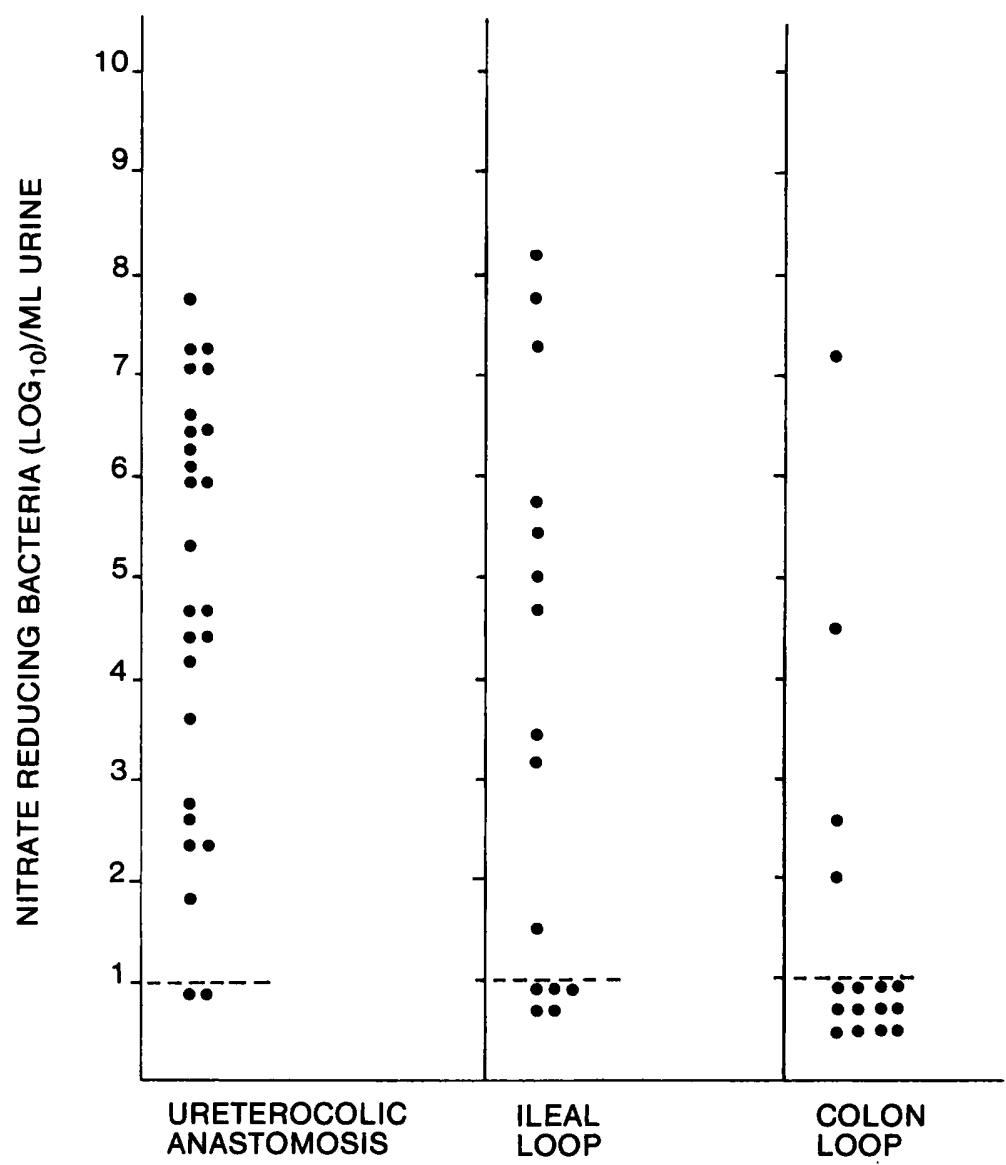

FIG. 2.-The number of nitrate-reducing bacteria/ml of urine from 26 patients with ureterocolic anastomoses, 15 with ileal loop and 16 with colon loop diversions. 
TABLE I

Major organisms isolated from urine of patients with ureterocolic anastomoses, ileal loop and colon loop diversions

\begin{tabular}{lcll}
\hline & \multicolumn{3}{c}{$\begin{array}{c}\text { Number of patients infected with the given } \\
\text { species/total number of patients with }\end{array}$} \\
\cline { 2 - 4 } Organisms isolated & $\begin{array}{l}\text { ureterocolic } \\
\text { anastomosis }\end{array}$ & $\begin{array}{l}\text { ileal } \\
\text { loop }\end{array}$ & $\begin{array}{c}\text { colon } \\
\text { loop }\end{array}$ \\
\hline Anaerobes & & & \\
Bacteroides spp & $21 / 26$ & $4 / 15$ & $0 / 16$ \\
Bifidobacterium spp & $3 / 26$ & $0 / 15$ & $0 / 16$ \\
Clostridium spp & $19 / 26$ & $2 / 15$ & $0 / 16$ \\
Veillonella spp & $7 / 26$ & $1 / 15$ & $0 / 16$ \\
Aerobes & $20 / 26$ & $7 / 15$ & $4 / 16$ \\
Enterobacteria & $25 / 26$ & $9 / 15$ & $2 / 16$ \\
Streptococci & $10 / 26$ & $2 / 15$ & $0 / 16$ \\
Lactobacilli & \multicolumn{3}{c}{} \\
\hline
\end{tabular}

\section{TABLE II}

The complexity of the bacterial flora isolated from urine of patients with three types of urinary tract diversion

\begin{tabular}{|c|c|c|c|c|c|c|}
\hline \multirow[b]{2}{*}{ Type of diversion } & \multirow{2}{*}{$\begin{array}{l}\text { Number of } \\
\text { urines examined }\end{array}$} & \multirow{2}{*}{$\begin{array}{l}\text { Number of } \\
\text { urines infected }\end{array}$} & \multicolumn{4}{|c|}{ Number of urines infected with } \\
\hline & & & 1 genus & 2 genera & 3-4 genera & $>4$ genera \\
\hline $\begin{array}{l}\text { Ureterocolic } \\
\text { anastomosis }\end{array}$ & 26 & 26 & 0 & 3 & 12 & 11 \\
\hline $\begin{array}{l}\text { Ileal loop } \\
\text { Colon loop }\end{array}$ & $\begin{array}{l}15 \\
16\end{array}$ & $\begin{array}{r}11 \\
6\end{array}$ & $\begin{array}{l}3 \\
6\end{array}$ & $\begin{array}{l}4 \\
0\end{array}$ & $\begin{array}{l}3 \\
0\end{array}$ & $\begin{array}{l}1 \\
0\end{array}$ \\
\hline
\end{tabular}

and 11 with five or more bacterial species. Ileal loop urines were of intermediate complexity; 11 of the 15 urines were infected, four with three or more genera and only three with a single organism.

\section{Discussion}

It was not surprising that rectal urines from patients with ureterosigmoidostomies was heavily infected with rich mixtures of faecal-type organisms. The flora differed from that of faeces in some interesting aspects. For example, the gram-positive non-sporing bacteria (lactobacilli and bifidobacteria) were grossly under-represented in the rectal urines; these organisms tend to be non-ureolytic and acid-tolerant, whereas rectal urine is highly alkaline and rich in urea.

The monobacterial infections found in the colon loops indicate infection from outside, rather than residual mucosal bacteria left at the time of diversion. Presumably infection in ileal loops arises in the same way, the complexity of the flora being due to multiple superinfections. It is notable that the complexity of the flora is very much less than that found in rectal urines and there is a relatively low proportion of anaerobes. The extensive literature on ileal loop urine bacteriology has recently been reviewed by Stewart, Cass and Matsen, (1979). The infection rate varied from $14-100 \%$ and is thought to be related to the volume of residual urine (Bergman, 1978; Stewart et al., 1979); where an aggressive surgical approach was taken to reduce the residual volume to a minimum the rate of infection was low. The apparent infection rate also increased with the number of urine samples taken from each patient. We collected only a single sample of urine from each patient and did not measure the residual urine volume. 
It is difficult to explain the marked discrepancy between the infection rates in colon and ileal loop urines. The smaller risk of bacterial infection in colon conduits, if confirmed, has significant clinical implications. Whilst anti-refluxing 'tunnelling' (Leadbetter and Clarke, 1955) can be performed easily in colonic diversions, it poses technical difficulties in uretero-ileal anastomoses. Thus, most ureters are anastomosed to the ileum in such a way as to allow free reflux of urine into the upper urinary tract. Provided that this urine is sterile, reflux is not a major problem but reflux of infected urine will almost always result in renal parenchymal damage and pre-dispose to stone formation. Of the patients studied, those with ileal conduits and heavily infected urine and without anti-reflux ureteric anastomoses should, in the long term, fare worse than those with colonic conduits, whose upper tracts are, it is hoped, protected against reflux and whose urine contains many fewer bacteria.

In previous studies, much emphasis has been placed on the number of bacteria per $\mathrm{ml}$ of urine but the techniques used in this study have allowed us to detect a wider range of organisms than in previous studies. Clearly, the complexity of the infection may be as important as the total number of organisms per $\mathrm{ml}$ because mixed populations may act synergically in causing tissue damage as well as being much more difficult to treat with antibiotics. In this respect it is important to note that not only were fewer colon loops than ileal loops infected but also that the colon loops had only monobacterial infections whereas most of the urinary infections in ileal loops were mixed.

In addition, we have postulated that carcinogenic $\mathrm{N}$-nitroso compounds are formed and activated from urinary substrates by bacteria in patients with ureterosigmoidostomies and thus the risk of malignancy should be greatest in these patients where the prevalence of mixed urinary infection is greater. On these criteria, the risk of malignancy in isolated colonic conduits should be relatively insignificant, whereas the risk of cancer in ileal conduits should be intermediate between the risks with the two alternative forms of diversion. The first malignancy (adenocarcinoma) in an ileal loop was described by Shousha, Scott and Polak, (1978), 20 years after the diversion was performed for exstrophy. If our hypothesis is correct, and assuming a similar latency to that of malignancy at the ureterocolic anastomosis, this case may be the warning of many more to come.

It must be stressed that our hypothesis is still unproven, and further studies are required. If it is correct, however, the implication of this report is that, of the alternative forms of external diversion, colonic conduits offer the best protection against upper urinary tract deterioration and a lower risk of malignancy. Ureterosigmoidostomy on the other hand, carries a high risk of anastomotic cancer.

The same theory of endogenous carcinogen formation by bacteria can be applied to any situation where a mixed bacterial infection occurs in the urinary tract, e.g. bladder calculus, bilharzia and urethral stricture. It would seem reasonable to suggest that in all such situations the administration of a nitrite scavenger, such as ascorbate, would prevent $\mathrm{N}$-nitroso compound formation and possible subsequent malignancy.

We acknowledge the excellent technical assistance of Ms Elizabeth Lewis, and the cooperation of the nursing and clinical staff of the Institute of Urology. The work was supported financially by the Department of the Environment, the Cancer Research Campaign and Hoffman-LaRoche Ltd.

\section{REFERENCES}

Althausen, A. F., Hagen-CoOK, K. ANd Hendren, W. H. 1978. Non-refluxing colon conduit: experience with 70 cases. Journal of Urology, 120, 35-39.

Altwein, J. E., JoNAS, U. AND HohENFELLNER, R. 1977. Long-term follow-up of children with colonic conduit urinary diversion and ureterosigmoidostomy. Journal of Urology, 118, 832-836.

BERGMAN, B. 1978. Studies on patients with ileal conduit diversion with special regard to renal infection. Scandinavian Journal of Urology and Nephrology, Suppl. 47, 1-32.

Borriello, S. P., Hudson, M. J. AND Hill, M. J. 1978. Investigation of the gastrointestinal bacterial flora. Clinics in Gastroenterology; 7, 329-349. 
BRICKER, E. M. 1950. Bladder substitution after pelvic evisceration. Surgical Clinics of North America, 30, 1511-1521.

CORBETt, C. R. AND Lloyd-DAvies, R. W. 1976. Long term survival after urinary diversion. A reappraisal of ureterosigmoidostomy. European Urology, 2, 221-225.

CrOWTHER, J. S. 1971. Transport and storage of faeces for bacteriological examination. Journal of Applied Bacteriology, 34, 477-483.

Dunn, M., RoberTs, J. B., Smith P. J. ANd Slade, N. 1979. The long term results of ileal conduit urinary diversion in children. British Journal of Urology, 51, 458-461.

ELDER, D. D., MoISEY, C. U. AND REES, R. W. M: 1979. A long-term follow-up of the colonic conduit operation in children. British Journal of Urology, 51, 462-465.

Hicks, R. M., Walters, C. L., Elsebai, I., El Aasser, A-B., El Merzabini, M. and Gough, T. A. 1977. Demonstration of nitrosamines in human urine: preliminary observations on a possible etiology for bladder cancer in association with chronic urinary tract infections. Proceedings of the Royal Society of Medicine, 70, 413-417.

LEADBETTER, W. F. AND ClARKE, B. G. 1955. Five years experience with uretero-enterostomy by the "combined" technique. Journal of Urology, 73, 67-82.

Meynell, G. G. AND MeYnell, E. 1970. Theory and practice in experimental bacteriology, 2nd ed., Cambridge University Press, Cambridge.

MoGG, R. A. 1965. The treatment of neurogenic urinary incontinence using the colonic conduit. British Journal of Urology, 37, 681-686.

RICHIE, J. P. AND SkINNER, D. G. 1975. Urinary diversion: the physiological rationale for the non-refluxing colonic conduits. British Journal of Urology, 47, 269-275.

Shousha, S., ScotT, J. AND Polak, J. 1978. Ileal loop carcinoma after cystectomy for bladder exstrophy. British Medical Journal, 2, 397-398.

Stewart, M., Hill, M. J., Pugh, R. C. B. AND Williams, J. P. 1981. The role of N-nitrosamine in carcinogenesis at the ureterocolic anastamosis. British Journal of Urology, 53, 115-118.

Stewart, W.W., CASS, A. S. AND MATSEN, J. M. 1979. Bacteriuria with intestinal loop urinary diversion in children. Journal of Urology, 122, 528-531.

STILES, H. J. 1911. Epispadias in the female and its surgical treatment with a report of 2 cases. Surgery, Gynecology and Obstetrics, 30, 127-140.

WEAR, J. B. AND BARQUIN, O. P. 1973. Ureterosigmoidostomy: long term results. Urology, 1: 192-200. 